\title{
Growth changes and antioxidant activities of Romaine lettuce with plasma discharge water and bioblock treatment
}

\author{
Seo-Young Jeon', Jung-Min Sung ${ }^{2}$, Seung-Hoon Baek ${ }^{3}$, Ki-Hyun Kwon ${ }^{3 *}$ \\ ${ }^{1}$ Technical Assistance Center, Korea Food Research Institute, Wanju 55365, Korea \\ ${ }^{2}$ Research Group of Food Processing, Korea Food Research Institute, Wanju 55365, Korea \\ ${ }^{3}$ Research Group of Consumer Safety, Korea Food Research Institute, Wanju 55365, Korea
}

\section{플라즈마 방전수 및 바이오블록 처리를 달리한 로메인 상추의 생장변화 및 항산화 특성}

\author{
전서영 ${ }^{1} \cdot$ 성정민 $^{2} \cdot$ 백승훈 $^{3} \cdot$ 권기현 $^{3 *}$ \\ ${ }^{1}$ 한국식품연구원 기술지원센터, ${ }^{2}$ 한국식품연구원 가공공정연구단, \\ 3한국식품연구원 소비안전연구단
}

\begin{abstract}
This study intended to analyze growth changes and antioxidant activities of Romaine lettuce by different treatments of microbubble plasma discharge water and bioblock (far-infrared radiation). Hydroponics were performed in smart farm environments, and the used Romaine lettuce was the Caesar's Green variety. The treatment conditions of Romaine lettuce (TRL) are as follows: TRL-1 was treated with plasma discharge water and 30 bioblocks, and TRL-2 was treated with plasma discharge water and 40 bioblocks. On the other hand, TRL-3 was not treated. Romaine lettuce was grown for a total of 49 days and the growth changes were measured at every seven days. In growth changes, TRL-2 was significantly higher $(\mathbf{p}<0.05)$ than other treatments in germination rate and weight, leaf length, and leaf count. The total polyphenol and flavonoid contents were analyzed as similar levels between the samples, but TRL-2 showed higher antioxidant activities in ABTS radical scavenging (\%) compared to the other samples. As a result of this study, TRL-2 conditions are evaluated to affect the growth and antioxidant functions of Romaine lettuce.
\end{abstract}

Key words : Romaine lettuce, hydroponics, plasma discharge water, bioblock (far-infrared radiation), antioxidants

서 론

전 세계적으로 지구온난화 및 이상기후 변화, 환경오염 등 으로 인해 식량자원 생산의 불확실성이 증가하면서 안정적인 식량 공급을 해결하기 위해 식물공장의 필요성이 증대되고 있다. 외부 조건의 영향을 받지 않고 농작물에 대해 통제된 일정 시설 내에서 빛, 온도, 습도, $\mathrm{CO}_{2}$ 농도, 배양액 등 환경
조건을 인공적으로 정밀하게 조절이 가능한 식물공장(Seo 등, 2008)은 농작물 생육상태를 과학적으로 관리하므로 정밀농 업(precision agriculture)의 성격을 가진다. 이는 재배 농작물 의 생산성 및 품질을 향상시키며, 연중 자동적으로 연속 생산 이 가능하여 일반 농산물에 비해 균일화 및 규격화된 상품을 생산하고 병해충과 화학농약을 사용하지 않아 안전한 농산물 생산이 가능하다(Kim, 2009). 최근 수경재배(hydroponics)를

*Corresponding author. E-mail : kkh@kfri.re.kr, Phone : +82-63-2196-9258, Fax : +82-63-219-9876

Received 02 February 2021; Revised 12 March 2021; Accepted 01 April 2021.

Copyright (c) The Korean Society of Food Preservation.

This is an Open Access article distributed under the terms of the Creative Commons Attribution Non-Commercial License (http://creativecommons.org/licenses/by-nc/4.0) which permits unrestricted non-commercial use, distribution, and reproduction in any medium, provided the original work is properly cited. 
바탕으로 식물공장을 활용한 연구가 활발해지고 있으며, 양 액처리 방식에 따라 양액을 재사용하지 않는 비순환식 수경 재배와 양액을 재활용하는 순환식 수경재배로 나뉜다(Lee와 $\mathrm{Kim}, 2019)$. 수경 재배환경은 순환식 수경재배로 배양액을 흘려주며 산소를 공급해주는 방식으로, 배양액의 관리 효율 성은 높으나 양액으로 인한 부영양화, 미생물 증식, 이끼 증 가로 녹조류 피해가 있으며, 뿌리가 짓무르고 썩으며 집단 감 염의 위험성을 가진다. 위의 문제점을 감소시키기 위해 재배 시설 및 배양액의 살균 및 제거가 이루어지고 있는데(Kim 등, 2005), 모래여과(Park 등, 1998)나 자외선처리(Jang과 Kim, 2005; Lee와 Kim, 2019), 열탕여과 및 오존처리(Kim 등, 2005), 플라즈마 처리(Kim과 Park, 2017) 등의 연구가 있다. 이 중 플라즈마를 활용한 처리는 다른 처리에 비해 살균에 더 효과가 있다고 보고되어 있다. 플라즈마는 강한 전기적 힘 으로 인해 기체 분자가 이온과 전자로 나누어지는 상태로, 환 경 분야 및 생의학 분야에서 살균, 정화, 탈취 등에 활용되며, 물에 활용도가 높아 농업용수나 살균수로 쓰이기도 하는데, 이를 방전수라고 한다. 방전수에서 생성된 수산기(-OH)는 강 한 산화력을 지녀 박테리아 살균의 경우 기존의 과산화수소 나 오존처리보다 수십에서 수백 배 효율이 높으며(Park 등, 2019), 유해하지 않은 수준에서 친환경적 살균세척이 가능하 다. 물속에서 플라즈마를 발생시킨 후에 플라즈마가 없는 상 태인 방전수는 살균효과가 있어 과일 세척, 수질 정화, 폐수 처리 등에 활용된다. 뿐만 아니라 플라즈마는 활성화, 살균, 촉매의 고유한 특성을 가져 물리적, 화학적 자극으로 씨앗의 발아율이나 새싹 성장률을 향상시킬 수 있다고 보고되고 있 다(Yoo, 2015). Kim 등(2017)에 따르면 플라즈마 방전수를 콩나물 재배수로 이용한 결과, 성장률이 크게 개선되었고, 특 정 영양성분, 기능성물질 함량이 향상되었다고 보고하며, Ryu 등(2016)에 따르면 마이크로웨이브 플라즈마 활성수를 처리 한 상추와 페튜니아 유묘 처리구가 대조구보다 생육이 더 증 가했다고 보고하였다.

또한 식물의 생육을 촉진하기 위한 다양한 연구가 많이 이 루어져 있는데, 그 중 하나가 원적외선 에너지를 이용한 연구 이다. 원적외선이란 적외선 중 파장이 긴 것을 말한다. 파장
이 길어 열작용이 큰 전자파의 일종으로, 눈에 보이지 않고 물질에 잘 흡수되며 유기화합물 분자에 대한 공진 및 공명 작용이 강해 가열 매체 없이 직접 작물에 조사되므로 에너지 효율이 높다. 이러한 열작용은 각종 세균을 없애며, 모세혈관 을 확장시켜 혈액순환과 세포조직 생성, 생육촉진 및 물질농 축에 도움이 된다고 보고되어 있다(Chee, 2001). Cho(2009) 의 연구에 따르면 원적외선 처리수에서 성장한 무의 자엽이 음용수보다 1.25 배 높게 성장하였고, 무 크기가 상대적으로 컸다고 보고되어 있다. 또한, 원적외선 조사 시 수분을 많이 함유한 작물은 신진대사 촉진으로 생육이 활발해지고 품질이 향상되는 것으로 보고하였다(Kim 등, 2009).

따라서 본 연구는 담수경 양액재배를 바탕으로 로메인 상 추에 마이크로버블 플라즈마 방전수 및 바이오블록(원적외선) 을 활용하여 로메인 상추의 생장변화를 확인하고 항산화능을 분석하여 로메인 상추 생육환경 조건을 확립하고자 하였다.

\section{재료 및 방법}

\section{재료}

본 실험에서 사용된 시료는 엽채류 중 시저스 그린 로메인 상추(Lactuca sativa Romaine L.) 품종 씨앗(Asia Jongmyo, Seoul, Korea)을 구입하여 실험하였다.

\section{생육환경 조건}

본 생육실험은 전북농업기술원 과채류연구소 내에 스마트 팜 생육환경에서 생육 test bed는 $500 \mathrm{~cm} \times 30 \mathrm{~cm} \times 20 \mathrm{~cm}$ 로 제작하고, $150 \mathrm{~cm} \times 30 \mathrm{~cm}$ 스티로폼 베드를 test bed 내에 띄 워서 담수경 재배하였다. 로메인 상추 씨앗을 물에 적셔 스티 로폼 베드에 $15 \mathrm{~cm}$ 간격으로 고무 홀더에 삽입하고 상부를 분무하였다. 로메인 상추(TRL)의 처리 조건은 Table 1과 같 다. $\mathrm{Ca}, \mathrm{Mg}, \mathrm{Na}, \mathrm{K}$ 등이 함유된 미네랄 양액을 사용하였고, 설치된 test bed 안쪽 바닥에 바이오블록(원적외선)을 2줄로 배열하고, 처리구 TRL-1은 바이오블록을 약 $30 \mathrm{~cm}$ 간격으로 30 개, TRL-2는 $25 \mathrm{~cm}$ 간격으로 40개를 배치하였다. 바이오 블록은 현무암 원석을 300-1,000 mesh로 분쇄 후 용해로

Table 1. Treatment conditions for the growth of Romaine lettuce

\begin{tabular}{ccccc}
\hline \multirow{2}{*}{ Test bed } & \multicolumn{3}{c}{ Condition } \\
\cline { 2 - 5 } & Bioblock (ea) & $\mathrm{O}_{2}$ supply & Plasma discharge water & Nutrient solution \\
\hline TRL ${ }^{1)}-1$ & 30 & 0 & 0 & 0 \\
TRL-2 & 40 & 0 & 0 & 0 \\
TRL-3 & $\times$ & 0 & $\times$ & 0 \\
\hline
\end{tabular}

${ }^{1)} \mathrm{TRL}$, treated Romaine lettuce. 
$1,500-2,000^{\circ} \mathrm{C}$ 기준으로 용해하여 각 지름 7-8 cm, 두께 2-3 $\mathrm{mm}$, 중량 $40 \mathrm{~g}$ 으로 제조한 것을 사용하였으며, 바이오블록 방사에너지 $\left(\mathrm{W} / \mathrm{m}^{2} \cdot \mu \mathrm{m}, 37^{\circ} \mathrm{C}\right)$ 는 $3.57 \times 10^{2}$ 이고, 방사율 $(5-20$ $\mu \mathrm{m})$ 은 0.926 을 나타냈다.

플라즈마 장치 설계는 총 세 부분으로 나뉘어 전원부, 발 진부, 방전부로 센서 베드에 연결하여 조절하고, $150 \mathrm{~mm} \times$ $800 \mathrm{~mm}$ 마이크로버블 제조장치(MVI-408, Wilo Co., Busan, Korea)를 중간부에 연결하였다. 마이크로버블 제조 장치는 직경이 $50 \mu \mathrm{m}$ 이하인 기포를 발생하도록 조건을 최적화하였 다. 수경재배 시스템의 양액 순환 과정은 3 일 1 회 회수되도록 설정하고, 재활용 순환수 조건을 $\mathrm{EC} 0.5$ 이하, $\mathrm{pH}$ 5.0-7.0, DO $10 \mathrm{ppm}$ 이상으로 설정하였다. 재배 환경 온도 $19.5 \pm 2.0^{\circ} \mathrm{C}$, 습도 $43 \pm 3 \% \mathrm{RH}$ 를 유지하였다.

생육기간은 총 49일간 재배하여 종자 이식은 2020년 1월 23 일에 심고, 1 월 29일까지 7일간 발아하여 7일 간격으로 분 석하여 2020년 3월 12 일에 재배를 종료하였다. 재배기간 동 안 발아율 및 생장변화(중량, 잎 길이 및 잎 개수)를 측정하 였다.

\section{추출물 제조}

총 49일간 재배한 로메인 상추(TRL)를 각 베드에서 무작위 로 채취하였다. 잎과 뿌리 부분을 분리하여 잎 부분만 한꺼번에 동결건조한 후 분말화하여 사용하였다. 추출방법은 각각 다른 시험관에 일정 중량을 칭량하고, Choi 등(2013)의 실험방법을 수정하여 각 다른 시험관에서 시료를 추출하였다. 동결건조 상 추 잎 분말 $0.1 \mathrm{~g}$ 을 $2 \mathrm{~mL}$ 의 $80 \% \mathrm{MeOH}$ 에 $50^{\circ} \mathrm{C}$ 에서 1 시간 진탕 추출(Mujigae SD-120H, Seongdong-ultra, Seoul, Korea) 하고, $4^{\circ} \mathrm{C}, 10,000 \mathrm{rpm}$ (Centrifuge 5804R, Eppendorf AG, Hamburg, Germany) 10 분간 원심분리한 후 $0.45 \mu \mathrm{m}$ syringe filter(RC25 Syringe filter 17765, Sartorius AG, Göttingen, Germany)로 여과하고, 희석하여 각 실험에 사용하였다.

\section{총폴리페놀 함량 측정}

총폴리페놀 함량은 Singleton과 Rossi(1965)의 Folin-Denis 방법을 수정하여 측정하였다. 일정 농도로 희석한 시료 100 $\mu \mathrm{L}$ 에 $2 \%$ 의 $\mathrm{Na}_{2} \mathrm{CO}_{3} 2 \mathrm{~mL}$ 를 첨가하여 3분 동안 상온에서 방 치시킨 다음, 1 N Folin-Ciocalteu 시약(Sigma-Aldrich Co., St. Louis, MO, USA) $100 \mu \mathrm{L}$ 를 넣은 후 $35^{\circ} \mathrm{C}$ 에서 11 분 반 응시켰다. 이후 흡광기기(Jasco V-730 Spectrophotometer, Jasco Corp., Tokyo, Japan)를 사용하여 $750 \mathrm{~nm}$ 에서 흡광도 를 측정하였다. 총폴리페놀 함량은 gallic acid(Sigma-Aldrich $\mathrm{Co}$.)를 표준물질로 하여 산출하였고, 동결건조 상추 $100 \mathrm{~g}$ 당 $\mathrm{mg}$ gallic acid equivalent(GAE, dry basis)로 함량을 나타 냈다.

\section{총플라보노이드 함량 측정}

총플라보노이드 함량은 Moreno 등(2000)의 방법을 수정 하여 측정하였다. 시료 $100 \mu \mathrm{L}$ 에 증류수 $1 \mathrm{~mL}$ 와 $5 \% \mathrm{NaNO}_{2}$ 용액 $75 \mu \mathrm{L}$ 를 넣은 후 상온에서 5 분간 반응시켰다. 이후 $10 \% \mathrm{AlCl}_{3} \cdot 6 \mathrm{H}_{2} \mathrm{O}$ 용액 $150 \mu \mathrm{L}$ 를 첨가하고, 6 분 동안 상온 에서 방치시킨 후, $1 \mathrm{M} \mathrm{NaOH}$ 용액 $500 \mu \mathrm{L}$ 를 첨가하여 11분 동안 발색시키고 $510 \mathrm{~nm}$ 에서 흡광도를 측정하였다. 총플라 보노이드 함량은 (+)-catechin hydrate(Sigma-Aldrich Co.) 표 준곡선을 이용하여 산출하였고, 동결건조 상추 $100 \mathrm{~g}$ 당 $\mathrm{mg}$ (+)-catechin hydrate equivalent(CHE, dry basis)로 함량을 나 타냈다.

\section{$\mathrm{DPPH}$ 라디칼 소거능 측정}

1,1-Dipheyl-2-picrylhydrazyl(DPPH) 라디칼 소거능은 Blois(1958)의 방법을 수정하여 측정하였다. 일정 농도로 희 석된 시료 $50 \mu \mathrm{L}$ 에 $0.2 \mathrm{mM} \mathrm{DPPH(Sigma-Aldrich} \mathrm{Co.)} \mathrm{용액}$ $1 \mathrm{~mL}$ 를 가한 후 암소에서 30 분간 반응시켜 흡광기기(Jasco V-730 Spectrophotometer)를 이용하여 $520 \mathrm{~nm}$ 에서 흡광도 를 측정하였다. 사용한 $0.2 \mathrm{mM} \mathrm{DPPH}$ 는 $99.9 \% \mathrm{MeOH}$ 에 녹 여 $520 \mathrm{~nm}$ 에서 흡광도가 $1.000 \pm 0.01$ 인 것을 사용하여 측정 하였다. 측정흡광도는 L-ascorbic acid(Sigma-Aldrich Co.)를 이용하여 만든 표준곡선을 이용하여 $\mathrm{DPPH}$ 라디칼 소거능 결과 값을 백분율 $(\%)$ 로 나타냈다.

\section{ABTS 라디칼 소거능 측정}

2,2'-Azino-bis-(3-ethylbenzothiazoline-6-sulfonic acid(ABTS) 라디칼 소거능은 $\operatorname{Re}$ 등(1999)의 방법을 수정하여 측정하였 다. $7 \mathrm{mM}$ ABTS 용액과 $2.45 \mathrm{mM}$ potassium persulfate를 $1: 1$ 로 혼합한 후 암소에서 약 24시간 반응시켰다. 이후 실험 직전에 ABTS 용액을 $735 \mathrm{~nm}$ 에서 흡광도가 $1.4 \pm 0.01$ 이 되도 록 phosphate buffer saline(pH 7.4)으로 희석하여 사용하였 다. 희석된 ABTS 용액 $1 \mathrm{~mL}$ 를 일정 농도로 희석한 시료 50 $\mu \mathrm{L}$ 에 첨가하여 암소에서 30 분간 실온 반응시켰다. 이후 흡광 기기(Jasco V-730 Spectrophotometer)를 사용하여 $750 \mathrm{~nm}$ 에 서 흡광도를 측정하였다. 측정흡광도는 $\mathrm{L}$-ascorbic acid (Sigma-Aldrich Co.)를 이용하여 만든 표준곡선을 이용하여 $\mathrm{ABTS}$ 라디칼 소거능 결과 값을 백분율(\%)로 나타냈다.

\section{통계분석}

실험결과는 SPSS 프로그램(21.00, IBM Corp., SPSS Inc, Chicago, IL, USA)을 이용하여 분산분석(ANOVA)법을 실 시하였고, 3회 반복 실험하고 실험군 간의 유의성은 Duncan's multiple range test로 $\mathrm{p}<0.05$ 수준에서 유의적 차이를 검증하 였다. 


\section{결과 및 고찰}

\section{발아율}

로메인 상추(TRL)의 발아율은 Table 2 와 같다. 모든 처리 구에서 약 7-14일 사이에 발아되었다. 재배 7일차 발아율이 81.7-86.7\%로 모든 처리구가 비슷한 수준이었으나, 14 일차 이후 TRL-2 처리구만 $100 \%$ 발아율을 나타내었고, 다른 처 리구는 7일차와 비슷한 수준을 유지하였다. 최종 발아율은 TRL-1은 $85 \%$ 이며, TRL-3은 $83.3 \%$ 로 나타났다. 이는 Park 등(2016)에 따르면 화산력 바이오블록을 처리한 페레니얼 레 이그라스 파종 후 초기 발아 1주 때에 발아율이 80-85\% 증가 되었다고 보고하였다. 또한, 초미세버블을 이용한 보리종자 연구에서 초미세버블이 종자의 발아속도 향상에 도움을 주며, 발아율이 15-20\% 향상되었다고 보고하여(Hwang 등, 2016) 본 실험에서도 마이크로버블 플라즈마 방전수 및 바이오블록 (원적외선)을 처리한 TRL-1, TRL-2가 높은 발아율을 보여
위 연구와 비슷한 결과를 나타냈다.

\section{중량 변화}

총 49일간 재배하여 수확한(2020년 3월 12일 재배종료) 로 메인 상추(TRL) 생장 상태는 Fig. 1과 같으며, 재배 일수에 따 른 중량 변화는 Fig. 2와 같다. 재배 21일차 TRL-1과 TRL-2 의 중량은 각 $0.76 \mathrm{~g}, 0.56 \mathrm{~g}$ 으로 처리구 간 비슷한 중량을 보였고, TRL-3 중량은 $0.09 \mathrm{~g}$ 으로 시료 중 낮은 중량을 나타 냈다. 이후 TRL-3은 중량이 거의 일정하게 유지된 반면에, TRL-1과 TRL-2의 중량은 각 $11.03 \mathrm{~g}, 12.61 \mathrm{~g}$ 으로 재배 42일 차까지 중량이 유의적으로 $(\mathrm{p}<0.05)$ 증가하였다. 재배 49 일차 에 모든 시료가 큰 증가폭을 보였으며, 그 중 TRL-2가 유의적 으로 $(\mathrm{p}<0.05)$ 높은 중량 증가를 나타냈다. Lee 등(2015)에 따 르면 방풍 수경재배 시 지하부의 배양액 차이가 뿌리의 발달 과 지상부의 생육에도 영향을 미친 것으로 판단된다는 결과를 보아 본 실험은 위 연구와 비슷한 결과를 보였다.

Table 2. Germination rate of Romaine lettuce by treatment conditions

\begin{tabular}{ccccccc}
\hline \multirow{2}{*}{ Sample } & \multicolumn{7}{c}{ Germination number (rate) } \\
\cline { 2 - 6 } & 7 days & 14 days & 21 days & 28 days & 35 days & Total \\
\hline TRL ${ }^{1)}-1$ & $49(81.7 \%)$ & $51(85 \%)$ & $51(85 \%)$ & $51(85 \%)$ & $51(85 \%)$ & $51(85 \%)$ \\
TRL-2 & $49(81.7 \%)$ & $60(100 \%)$ & $60(100 \%)$ & $60(100 \%)$ & $60(100 \%)$ & $60(100 \%)$ \\
TRL-3 & $52(86.7 \%)$ & $51(85 \%)$ & $50(83.3 \%)$ & $50(83.3 \%)$ & $50(83.3 \%)$ & $50(83.3 \%)$ \\
\hline
\end{tabular}

${ }^{1)}$ TRL, treated Romaine lettuce.
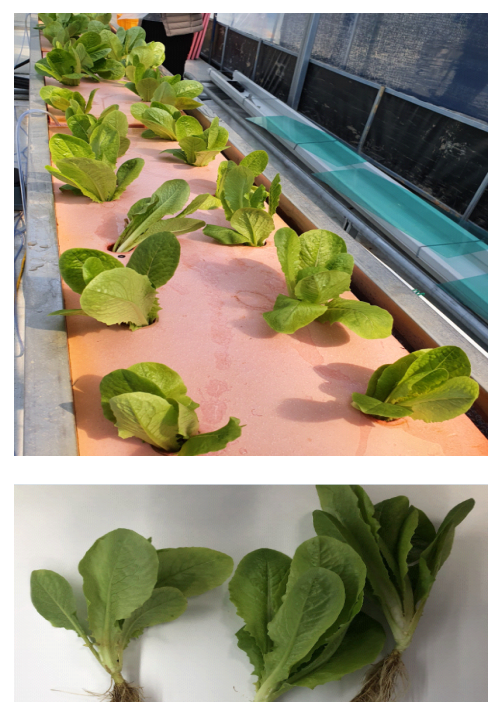

TRL-1
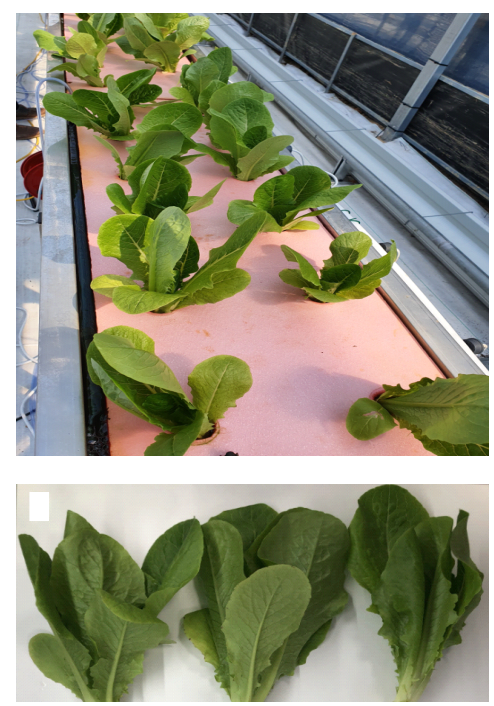

TRL-2
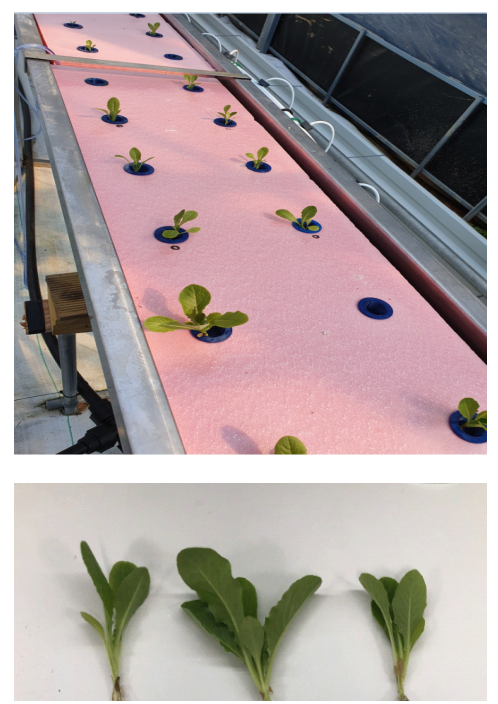

TRL-3

Fig. 1. Romaine lettuce cultivated for total periods of 49 days.

TRL, treated Romaine lettuce. 


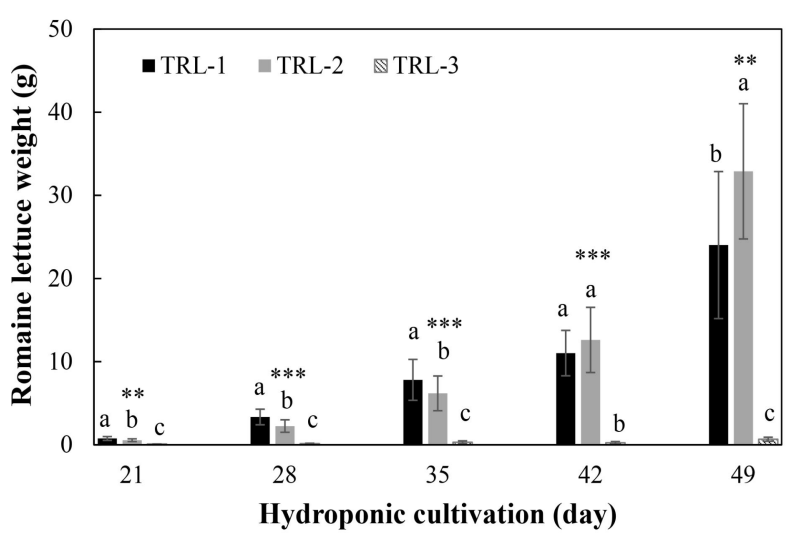

Fig. 2. Weight variation of Romaine lettuce by treatment conditions. TRL, treated Romaine lettuce.

Each value is mean $\pm \mathrm{SD}(\mathrm{n}=3)$. Values with different letters above the bars are significantly different $\mathrm{p}<0.05$ by Duncan's multiple range tests.

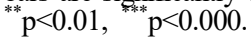

\section{잎 길이 및 개수}

재배 일수에 따라 잎 길이 및 개수 변화는 각각 Fig. 3, Fig. 4 와 같다. 잎 길이는 재배 22 일 차 TRL-1이 다른 시료에 비해 가장 길게 나타났다 $(\mathrm{p}<0.05)$. 그러나 재배 42 일차에는 TRL-1과 TRL-2의 잎 길이가 각각 $14.87 \mathrm{~cm}, 14.20 \mathrm{~cm}$ 로 비 슷한 경향을 나타냈고, 재배 49일차에는 TRL-1과 TRL-2의 잎 길이가 각각 $18.79 \mathrm{~cm}, 21.98 \mathrm{~cm}$ 로 TRL-2가 처리구 중 유의 적으로 $(\mathrm{p}<0.05)$ 높은 성장을 나타냈다. 반면에, TRL-3은 잎 길이의 변화가 가장 낮게 나타났다. 잎 개수 결과, 또한 잎 길 이와 비슷한 경향으로 나타났다(Fig. 4). 재배 7일차부터 49일 차까지 TRL-1과 TRL-2는 유의적인 $(\mathrm{p}<0.05)$ 경향으로 잎 개 수가 증가하는 반면에, TRL-3은 처리구 중 적은 잎 개수로

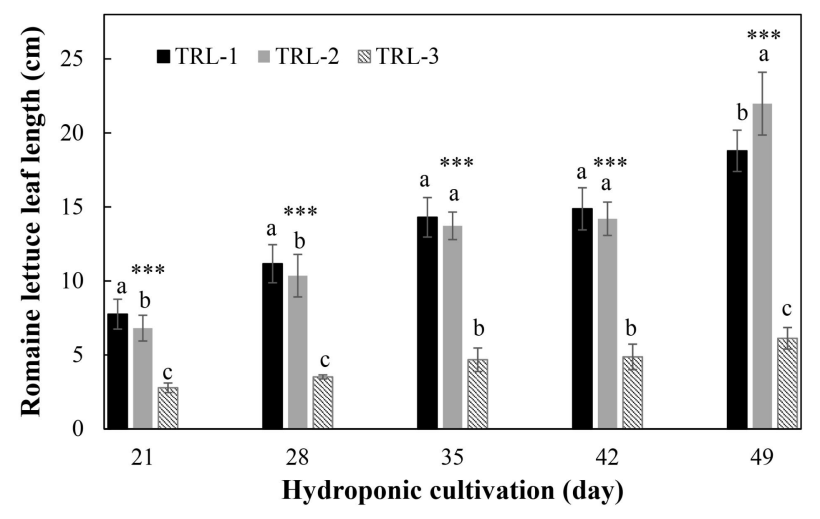

Fig. 3. Variation of leaf length of Romaine lettuce according to treatment conditions.

TRL, treated Romaine lettuce.

Each value is mean \pm SD $(n=3)$. Values with different letters above the bars are significantly different $p<0.05$ by Duncan's multiple range tests. $\mathrm{p}<0.000$.

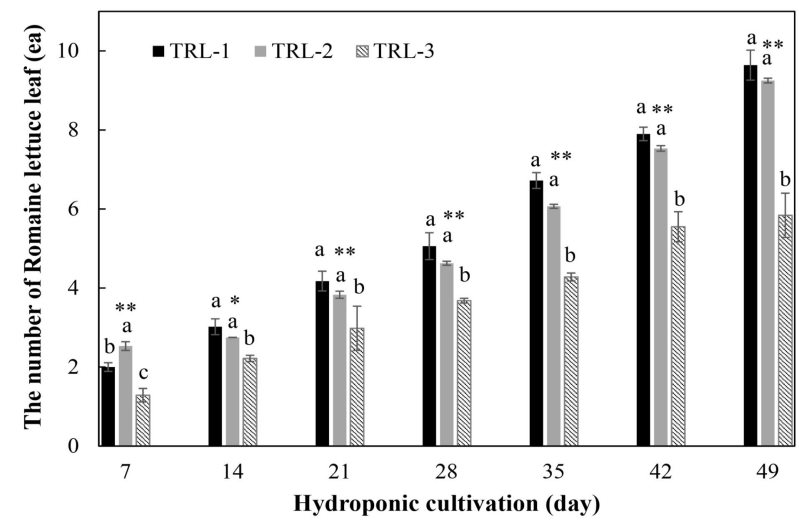

Fig. 4. Variation of the number of leaves of Romaine lettuce according to treatment conditions.

TRL, treated Romaine lettuce.

Each value is mean \pm SD $(n=3)$. Values with different letters above the bars are significantly different $\mathrm{p}<0.05$ by Duncan's multiple range tests. ${ }^{*} \mathrm{p}<0.05,{ }^{*} \mathrm{p}<0.01$.

나타났다. 이는 플라즈마 방전수를 처리한 식물에서 그렇지 않은 식물에 비해 생장이 촉진되며, 뿌리 활성에 영향을 준다 는 연구결과와 비슷한 경향을 보였다(Kim과 Park, 2017; $\mathrm{Ryu}$ 등, 2016). 또한, 마이크로버블을 이용한 담수경 재배 상 추의 지상부 생육이 유의적으로 증가했다고 보고되어 있으며 (Park과 Kurata, 2009), Kim 등(2017)의 연구에서도 콩나물 재배수로 플라즈마 방전수를 이용하였을 때에 성장률이 크게 개선되었다는 보고와도 비슷한 결과로 나타났다. 따라서 TRL-1과 TRL-2는 마이크로버블 플라즈마 방전수 및 바이오 블록(원적외선) 처리로 인해 중량, 잎 길이 및 잎 개수 등 생 장에 영향을 받은 것으로 판단되며, 처리하지 않은 TRL-3보 다 유의적으로 $(\mathrm{p}<0.05)$ 높은 결과를 나타냈다.

\section{총폴리페놀 및 총플라보노이드 함량}

로메인 상추(TRL) 총폴리페놀 및 총플라보노이드 함량은 Table 3 과 같다. 총폴리페놀 함량(mg GAE/100 g sample)은 TRL-1은 58.65 \pm 1.05 , TRL-2는 59.14 \pm 0.23 그리고 TRL-3은 $60.96 \pm 1.17$ 로 처리구 간 유의적인 $(\mathrm{p}<0.05)$ 차이를 보였으나 비 슷한 함량을 나타냈다. 또한 총플라보노이드 함량 $(\mathrm{mg} \mathrm{CHE} / 100$ $\mathrm{g}$ sample)은 TRL-1은 46.08 \pm 0.38 , TRL-2는 45.70 \pm 0.10 그리 고 TRL-3은 $46.35 \pm 0.13$ 으로 처리구 간 유의적인 $(\mathrm{p}<0.05)$ 차 이를 보였으나 비슷한 함량을 나타냈다. Woo 등(2020)에 따르 면 녹색 상추의 주요 화합물은 페놀 화합물과 관련하여 플라본 과 플라보놀도 비슷한 경향으로 나타난다고 보고되어 있다.

\section{DPPH 라디칼 소거능}

로메인 상추(TRL) DPPH 라디칼 소거능은 Fig. 5와 같다. 
Table 3. Total polyphenolics and total flavonoid contents of Romaine lettuce

\begin{tabular}{ccc}
\hline sample & $\begin{array}{c}\text { Total polyphenol content } \\
(\mathrm{mg} \mathrm{GAE}) / 100 \mathrm{~g} \\
\text { sample })\end{array}$ & $\begin{array}{c}\text { Total flavonoid content } \\
\left.(\mathrm{mg} \mathrm{CHE})^{3}\right) / 100 \mathrm{~g} \\
\text { sample })\end{array}$ \\
\hline $\mathrm{TRL}^{1)}-1$ & $58.65 \pm 1.05^{\mathrm{b} 4)}$ & $46.08 \pm 0.38^{\mathrm{ab}}$ \\
TRL-2 & $59.14 \pm 0.23^{\mathrm{ab}}$ & $45.70 \pm 0.10^{\mathrm{b}}$ \\
TRL-3 & $60.96 \pm 1.17^{\mathrm{a}}$ & $46.35 \pm 0.13^{\mathrm{a}}$ \\
F-value & $5.290^{* 5}$ & $5.622^{*}$ \\
\hline
\end{tabular}

${ }^{1)} \mathrm{TRL}$, treated Romaine lettuce.

${ }^{2)} \mathrm{GAE}$, gallic acid equivalent.

${ }^{3)} \mathrm{CHE},(+)$-catechin hydrate equivalent.

${ }^{4)}$ Values are mean \pm SD of triplicate determination. Different letters within a $*$ column are significantly different $(\mathrm{p}<0.05)$. ${ }^{5} \mathrm{p}<0.05$.

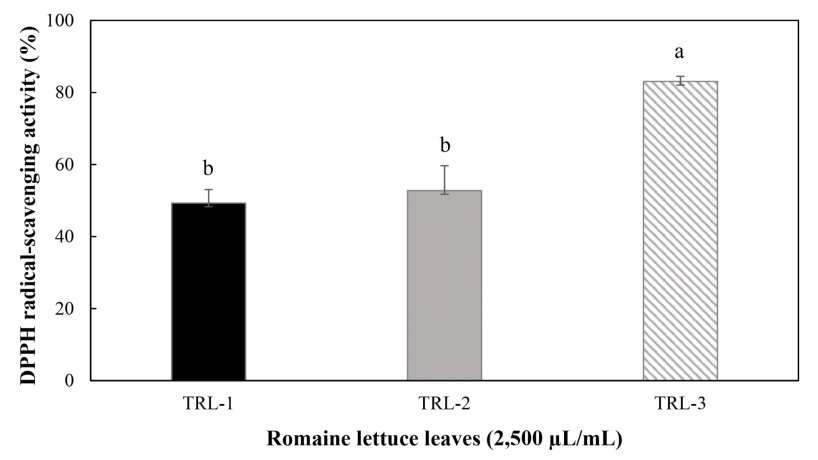

Fig. 5. DPPH free radical scavenging activities of Romaine lettuce. TRL, treated Romaine lettuce.

Each value is mean $\pm \mathrm{SD}(\mathrm{n}=3)$. Values with different letters above the bars are significantly different $p<0.05$ by Duncan's multiple range tests.

$\mathrm{DPPH}$ 라디칼 소거능(2,500 $\mu \mathrm{g}$ L-ascorbic acid/g sample)은 TRL-3(83.06\%)에 비해 성장이 촉진된 TRL-1은 $49.30 \%$, 그 리고 TRL-2는 52.76\%로 나타났다. Kim 등(2019)의 연구에 따르면 귀리의 발아가 진행됨에 따라 유의적으로 $\mathrm{DPPH}$ 와 $\mathrm{ABTS}$ 가 증가하다가 성장이 진행될수록 $\mathrm{DPPH}$ 와 $\mathrm{ABTS}$ 라 디칼 소거능이 감소하였다고 보고하고 있다. 이에 본 연구에 서 성장이 촉진된 TRL-1과 TRL-2에 비해 TRL-3의 DPPH와 $\mathrm{ABTS}$ 라디칼 소거능이 높게 나타난 것으로 판단된다.

\section{ABTS 라디칼 소거능}

로메인 상추(TRL) ABTS 라디칼 소거능은 Fig. 6과 같다. $\mathrm{ABTS}$ 라디칼 소거능(2,500 $\mu \mathrm{g}$ L-ascorbic acid/g sample)은 TRL-3(80.92\%)에 비해 성장이 촉진된 TRL-1은 $34.54 \%$ 그 리고 TRL-2는 42.63\%로 나타났다. TRL-1(34.54\%)에 비해 TRL-2가 42.63\%로 높은 ABTS 라디컬 소거능(\%)을 나타냈

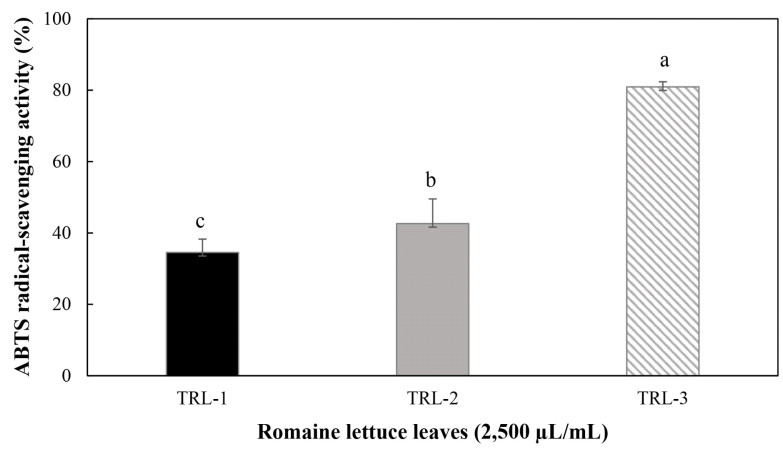

Fig. 6. ABTS free radical scavenging activities of Romaine lettuce. TRL, treated Romaine lettuce.

Each value is mean \pm SD $(n=3)$. Values with different letters above the bars are significantly different $p<0.05$ by Duncan's multiple range tests.

으며, TRL-3의 결과 또한 DPPH 라디컬 소거능 경향과 비슷 한 결과를 나타냈다.

\section{요 약}

본 연구는 마이크로버블 플라즈마 방전수 및 바이오블록 (원적외선) 처리를 달리하여 로메인 상추의 생장변화 및 항 산화 특성을 분석하고자 하였다. 스마트 팜 환경에서 담수경 재배로 수행하였으며, 로메인 상추는 시저스 그린 품종을 사 용하였다. 로메인 상추(TRL) 처리조건은 TRL-1에 마이크로 버블 플라즈마 방전수 및 30 개의 바이오블록을 처리하고, TRL-2에는 마이크로버블 플라즈마 방전수 및 40개의 바이 오블록을 처리하였으나, TRL-3에는 처리하지 않았다. 로메 인 상추는 총 49 일간 재배하였고, 7일 간격으로 성장 변화를 측정하였다. 성장 변화에서 TRL-2는 발아율 및 중량, 잎 길 이 및 개수에서 다른 처리구에 비해 유의적으로 $(\mathrm{p}<0.05)$ 높 았다. 총폴리페놀과 플라보노이드 함량은 처리구 간 비슷한 함량으로 분석되었으나, $\mathrm{ABTS}$ 라디칼 소거능 $(\%)$ 에서는 TRL-2가 높은 소거능을 나타냈다. 본 연구결과, TRL-2 조건 이 로메인 상추의 생장 및 항산화 특성에 영향을 주는 것으로 판단된다.

\section{감사의 글}

본 연구는 전라북도 혁신성장 $\mathrm{R} \& \mathrm{D}+$ 사업(과제번호 $\mathrm{RA}$ 201905-03-C4)의 지원에 의해 수행되었음.

\section{Conflict of interests}

The authors declare no potential conflict of interest. 


\section{ORCID}

Seo-Young Jeon https://orcid.org/0000-0002-1703-8932

Ki-Hyun Kwon https://orcid.org/0000-0002-1811-5434

\section{References}

Blois MS. Antioxidant determinations by the use of a stable free radical. Nature, 181, 1199-1200 (1958)

Chee CK. The proceedings of the Korean institute of illuminating and electrical installation engineers. J Korean Inst IIIum Electr Install Eng, 15, 4-13 (2001)

Cho BH. Effect of the far infrared irradiated water on the growth of the cotyledons, hypocotyls and roots of the spring radishes. Anal Sci Technol, 22, 277-284 (2009)

Choi CS, Lee JG, Jang YA, Lee SG, Oh SS, Lee HJ, Um YC. Effect of artificial light sources on growth and quality characteristics of leaf lettuce in closed plant factory system. J Agric Life Sci, 47, 23-32 (2013)

Chung YA, Lee JK. Antioxidative properties of phenolic compounds extracted from black rice. J Korean Soc Food Sci Nutr, 32, 948-951 (2003)

Hwang MS, Oh SH, Lee JI, Han JW, Kim JM. Effect of nanobubbles on the seed germination. Korean J Plant Res, 29, 574-578 (2016)

Jang IS, Kim JY. Water treatment sterilization technology using ultraviolet light. The proceedings of the Korean Institute of Illuminating and Electrical Installation Engineers, 19, 14-21 (2005)

Kim DS, Park YS. Effects of intermittent operation of plasma and electrolysis processes on lettuce growth and nutrient solution components. J Environ Sci Int, 26, 109-118 (2017)

Kim HJ, Li H, Kang TH, Ning XF, Han CS, Cho SC. Growth characteristics of cherry tomato in greenhouse using far infrared heating systems. J Biosyst Eng, 34, 161-166 (2009)

Kim JH, Paek KY, Kim TJ, Kim SD, Lee CH, Yun T. Effect of ozone water on cut flower quality by solution culture Dendranthema grandiflorum 'Baegkwang'. J Hort Sci Technol, 23, 301-305 (2005)

Kim JH. Trends and prospects of plant factories. KREI Repository, Korea Rural Economic Research Institute, 61, p 3-5 (2009)
Kim MJ, Kim SB, Choi AJ, Lee YY, Choe JS. Antioxidant activity and functional components of germinated oats according to the sprout length. J Korean Soc Food Sci Nutr, 48, 1337-1344 (2019)

Kim YJ, Lee EJ, Koo OK, Kim JS. Bean sprout cultivation method using plasma-discharged water. Korea No. KR101782565B1 (2017)

Lee GJ, Heo JW, Jung CR, Kim HH, Yoon JB, Kim DE, Nam SY. Effects of plant factory cultural systems on growth, vitamin $\mathrm{C}$ and amino acid contents, and yield in hydroponically grown Peucedanum japonicum. J BioEnviron Con, 24, 281-286 (2015)

Lee SY, Kim YC. Water treatment for closed hydroponic systems. J Korean Soc Environ Eng, 41, 501-513 (2019)

Moreno MIN, Isla MI, Sampietro AR, Vattuone MA. Comparison of the free radical scavenging activity of propolis from several regions of Argentina. J EthnoPharmacol, 71, 109-114 (2000)

Park JS, Kurata K. Application of microbubbles to hydroponics solution promotes lettuce growth. Hort Technology, 19, 212-215 (2009)

Park KW, Lee GP, Kim MS, Lee SJ, Seo MW. Control of several fungi in the recirculating hydroponic system by modified slow sand filtration. Hort Sci Technol, 16, 347-349 (1998)

Park SH, Park JY, Choe WH. Origin of hydroxyl radicals in a weakly ionized plasma-facing liquid. Chem Eng J, 378, 122163 (2019)

Park SY, Nam BH, Kim JM, Choi KB, Yeon KS, Kim YS. Vegetation and water purification characteristics of lapilli-bio block. J Korean Soc Agric Eng, 58, 47-54 (2016)

Re R, Pellegrini N, Proteggente A, Pannala A, Yang M, Rice-Evans C. Antioxidant activity applying an improved ABTS radical cation decolorization assay. Free Radic Biol Med, 26, 1231-1237 (1999)

Ryu JH, Kwon S, Shin JH, Hong YC. Improving seedling growth by microwave plasma activated-water. Paper presented at $104^{\text {th }}$ Annual Spring Conference of the Korean Society For Horticultural Science, May 25, Changwon, Korea (2016)

Seo SG, Gang SW, Beak JP, Kim SH, Park KW, Lee YB. Plant Factory. World Science, Seoul, Korea, p 10-28 (2008) 
Singleton VL, Rossi JA. Colorimetry of total phenolics with phosphomolybdic-phosphotungstic acid reagents. Am J Enol Viticult, 16, 144-158 (1965)

Woo Y, Kim SJ, Kim MR. Quality characteristics and antioxidant activities of Sulgidduk added with Lactuca sativa. Korean J Food Cookery Sci, 36, 50-57 (2020)

Yoo SJ. Status of plasma technology applied to agriculture and foods. Vacuum Magazine, 2, 4-8 (2015) 